\title{
TAPETUM TYPES AND FORMS IN ANGIOSPERMS
}

\author{
Ivan I. Shamrov ${ }^{1,2, \#}$, Galina M. Anisimova ${ }^{2}$, and Anastasija A. Babro² \\ ${ }^{1}$ Herzen State Pedagogical University of Russia, St. Petersburg, 48 Embankment River Moyka, 191186, RUSSIA \\ ${ }^{2}$ Komarov Botanical Institute, Russian Academy of Sciences, 2 Popov Str., 197376, St. Petersburg, RUSSIA \\ \# Corresponding author, ivan.shamrov@gmail.com
}

Communicated by Isaak Rashal

\begin{abstract}
Based on the analysis of literature and our own data, we have suggested a new version of the typification of types and forms of the tapetum. It is proposed to distinguish two types of tapetum: parietal and periplasmodial. Parietal tapetum lines the locule of microsporangium and this position is maintained throughout the development. A periplasmodial tapetum is characterised by the formation of a coenocyte as a result of the fusion of protoplasts, while the cytoplasm and nucleus are located not only between the developing microspores and pollen grains, but also come into contact with the inner layers of the cavity. The differences between tapetum types relate to the peculiarities of structural and temporal reorganisation in anther development. The protoplasts that form after the disappearance of the cell walls (usually at the stage of microspore tetrad, or after their disaggregation), gradually break down (form 1 - typical parietal tapetum), or they form protrusions inside the microsporangium cavity (form 2 - amoeboid tapetum). The protoplasts in the periplasmodial tapetum are formed before or during meiosis. They fuse resulting in a symplast. It is possible to distinguish two forms of periplasmodial tapetum: combining and invasing of protoplasts into the locule of microsporangium (form 1 - typical periplasmodial tapetum), and almost or partly fusion of protoplasts, which do not organise the invasions and maintain the initial position (form 2 - bordering symplast). Data on the diversity and structure of the tapetum, like any other characters, are used to clarify the position of taxa on the phylogenetic tree.
\end{abstract}

Key words: anther structure, development, typification, flowering plants.

\section{INTRODUCTION}

The anther of angiosperms is rather well studied. Some of its features discovered during comparative embryological investigations can be used to solve controversial questions in systematics and phylogeny. At present, there is a complex of unresolved problems in the study of anthers of flowering plants. They concern the initial stages of microsporangium development, the ways of layer formation in microsporangium wall and characteristics of layers in the course of development (Shamrov et al., 2020). The paramount purpose of that study was to identify the diversity of the tapetum, the features of its formation and structure.

Many classifications of microsporangium wall formation were worked out on the basis of features of parietal tissue formation. The first classification was presented by Batygina et al. (1963). Using the development mode of parietal layers, there were distinguished two types: Solanaceae (centrifugal way) and Umbelliferae (centripetal way). Other types (Poaceae and Ericaceae) from this classification were divided because of tapetum arising from the derivates of secondary archesporial cells, but not from parietal layers (these types were not confirmed further in literature). Of the four types of microsporangium wall formation (basic, dicotyledonous, monocotyledonous and reduced) proposed by Davis (1966), two types (basic and reduced) are controversial. In the classification by Teryokhin et al. (1993; 2002), the basic type was included as a complicated variation in the centripetal type, and the reduced type as a reduced variation in the centrifugal type.

As our studies have shown, the reduced as well as the basic types are variations of the centripetal type: the basic type is included in a complicated variation, while the reduced type is a modification of the typical variation (Shamrov et al., 2020). In some flowering plants (Allium caspium (Pall.) M. Bieb., Alliaceae (Shamrov, 2006; 2008a; 2008b); Rhodo- 
dendron schlippenbachii Maxim., R. luteum Sweet, Ericaceae (Shamrov and Babro, 2008); Kalanchoe nyikae Engl., Crassulaceae (Anisimova, 2016); Euphorbia seguieriana Neck., E. stepposa Zoz ex Prokh., Euphorbiaceae (Anisimova, 2019), at early stages of anther development, the group of initial cells (central and lateral) differentiates in the subepidermal layer, which produces both microsporangium wall layers and archesporium. As a result of periclinal division of the central subepidermal cell, the archesporial cell arises centrifugally, and the cell forming proximal (situated closer to the connective) part of the microsporangium wall - centripetally. Lateral subepidermal initial cells form lateral parts of microsporangium wall by the means of divisions. The outer layer (parietal cells) and the inner one (sporogenous cells) arise as a result of periclinal divisions of archesporial cells. The cells of the parietal layer divide periclinally and anticlinally producing layers of the distal part of the microsporangium wall. Sporogenous cells undergo a number of divisions and then transform into microsporocytes, or microspore mother cells.

\section{CHACTERISTICS OF MICROSPORANGIUM WALL LAYERS}

The microsporangium wall has great importance in the formation of haploid microspore tetrads and male gametophytes (pollen grains). The developmental changes in its structure are coordinated with microsporogenesis and microgametogenesis.

The layers of microsporangium wall differ not only by features of their genesis, but also by their structural characteristics. Every layer is characterised by the structure of its cell and carries out a specific function. Epidermis cells vary in size and perform various functions: protection, ensuring gas exchange and transpiration, and also take part in the attraction of pollinators. The cells often stretch, and small vacuoles combine in a single one, driving the nucleus away to the periphery. The outer tangental cell wall thickens and covers itself by a cuticle (Fig. 1, 1).

The layer located just under the epidermis, i.e. the outermost of the layers originated by parietal cell divisions, forms endothecium, achieving the higher grade of development at the time of pollen distribution (Fig. 1, 1). Many fibrous thickenings branch from the inner walls of endothecium cells. The cells of this layer lose their content early; they provide anther dehiscence in the area of stomium, usually by longitudinal slits in every theca. Dehiscence of thecae usually occurs after disintegration of their septa. An analysis of the available data indicates that in plants with the basic and dicotyledonous types of microsporangium wall formation (according to Davis, 1966), fibrous thickenings are formed not only in the subepidermal, but also in the remaining underlying layers. Consequently, the formation of multi-layered endothecium is characteristic of complicated variations of both centrifugal and centripetal types, proposed by Shamrov et al. (2020). Plants with flowers developing in water in the case of hyphydrogamy (Ceratophyllaceae, Cymodoceae, Najadaceae, Hydrocharitaceae) and species with cleistogamous flowers lack fibrous thickenings in the microsporangium wall (Fig. 1, 2). Also, plants with anthers opening by apical pores (Asclepiadaceae, Ericaceae, Solanaceae) have no fibrous thickenings. The walls of epidermal cells produce the thickenings (therefore such a layer is called exothecium, by analogy with endothecium) and also the walls of cells underlying pores like a roll. A special case is described in Chrysanthemum morifolium Ramat., Asteraceae (Fei et al., 2016). Its cultivar with dehiscing anthers (Qx-097) has endothecium with fibrous thickenings. In another cultivar (Qx-007), anthers do not dehisce as a result of fibrous thickenings missing in endothecium. In addition the latter have septae in thecae and stomium from enlarged cells. In the anthers, high hydratation and high quantity of $\mathrm{K}^{+}$and $\mathrm{Ca}^{2+}$ iones are observed. There are one or more middle layers under endothecium; they consist of not very large cells and as a rule disintegrate after completion of meiosis in microspore mother cells. In the course of development, transitory starch may accumulate in cells of middle layers.

\section{DEVELOPMENT AND STRUCTURE OF TAPETUM}

The innermost layer of microsporangium wall is tapetum. Its cells often have tabular shape, are filled with dense cytoplasm and contain one or sometimes several nuclei. Tapetum may be homomorphous (its cells have similar structure) or heteromorphous (cells placed near connective are often larger, papilliform, and the number of layers may be more) (Kamelina, 1981; 2009). The main function of tapetal tissue is to provide microsporocytes, developing microspores and pollen grains with nutrients, the most im-
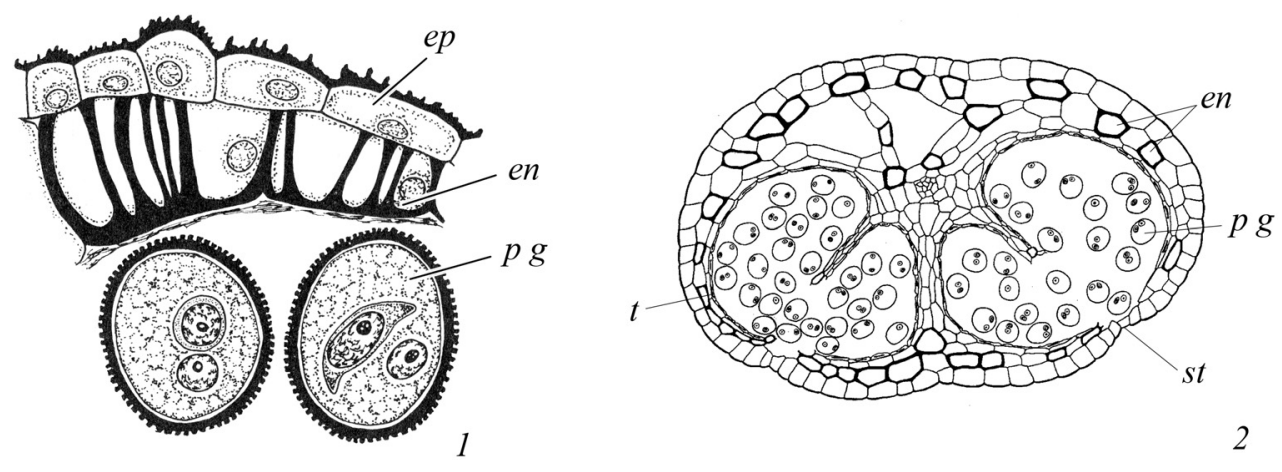

Fig. 1. Structure of mature anther in Gagea stipitata Merckl. ex Bunge (Liliaceae) and Ceratophyllum platyacanthum Cham. (Ceratophyllaceae) (Shamrov, 2015): wall of the mature anther in $G$. stipitata, there are fibrous thickenings in endothecium (1), and $C$. platyacanthum, fibrous thickenings in endothecium are absent, only walls of separate cells are thickened (2). en endothecium, ep - epidermis, $p g-$ pollen grain, $s t-$ stomium, $t-$ tapetum. 
portant of which are polysaccharides, enzymes, hormones, accumulating within microsporangium locule (Pacini, 2010).

Tapetal cells secrete callase - the enzyme for dissolution of callose walls of microspore tetrads. They produce sporopollenin for exine and orbicules (Ubish bodies) that are usually located on the inner plasma membrane and contact the developing pollen grains. Tapetal cells take part in composition of pollenkitt (consists of lipids and carotinoids) and trifina (consists of a mixture of hydrophilic and hydrophobic substances) encouraging pollination by insects (El-Ghazaly, 2002). In addition, the substances inhibiting processes of endothecium cell specialisation during the entire period of microsporogenesis are synthesied in tapetum. The inhibiting action after the completion of sporopollenin production terminates and tapetum begins to disintegrate; usually it takes place at the stage of vacuolated microspores. The formation of thickenings in endothecium cells occurs only after that (Chauhan, 1977). When tapetum persist for a long time, especially in plants with cytoplasmic male sterility, abortion of pollen can be seen, while endothecium cells do not pass to fibrous thickening formation, and anthers do not dehisce (Chauhan, 1979; Chauhan and Gupta, 2006). In some plants such processes are normal. In Escallonia rubra (Ruiz \& Pav.) Pers., Escalloniaceae (Kamelina, 1985) the start of fibrous thickening formation in the cells of 2-3-layered endothecium takes place only at the stage of 2-celled pollen grain with the generative cell being situated near the sporoderm. Mature pollen in this species is 3 -celled. Tapetum persists for a long time and disintegrates just before anther dehiscence. The longevity of tapetum, which ceases in the period of pollen grains formation, results in a later start of fibrous thickenings genesis in endothecium in some Euphorbiaceae species (Euphorbia iberica Boiss., E. petrophila C.A. Mey., E. seguieriana Neck., E. stepposa Zoz ex Prokh. (Anisimova, 2019)). As a rule, tapetal cells do not persist in mature anther.

In some plants (Gentianaceae) tapetum cells form trabecules, or septa (Shamrov, 1988) (Fig. 2, 1-5). In the walls of developing microsporangia of Gentiana lutea L. and Swertia iberica Fisch. ex Boiss. tapetum forms earlier on the inner side, then on the lateral sides and then from the parietal layer arising as a result of periclinal divisions of archesporial cells. The feature of anther development in these species is the embowed localisation of sporogenous cells; the inner tapetum occurs inside the bow and spreads near to the outer tapetum. This results in their closing together and formation of septate locules. The arising trabecules come across the locule radially and divide the sporogenous tissue into complexes of cells. In the course of development, the trabecule cells and tapetum disintegrate; they remain up to the stage of 2-celled pollen grains (mature pollen is 3-celled). The cells of inner tapetum disintegrate first, then trabecules degenerate, and the cells of lateral and outer tapetum are the last. The possibility of septa formation in anthers is not excluded, for example as in Berberis vulgaris L. (Budell, 1964), and also in some species belong-

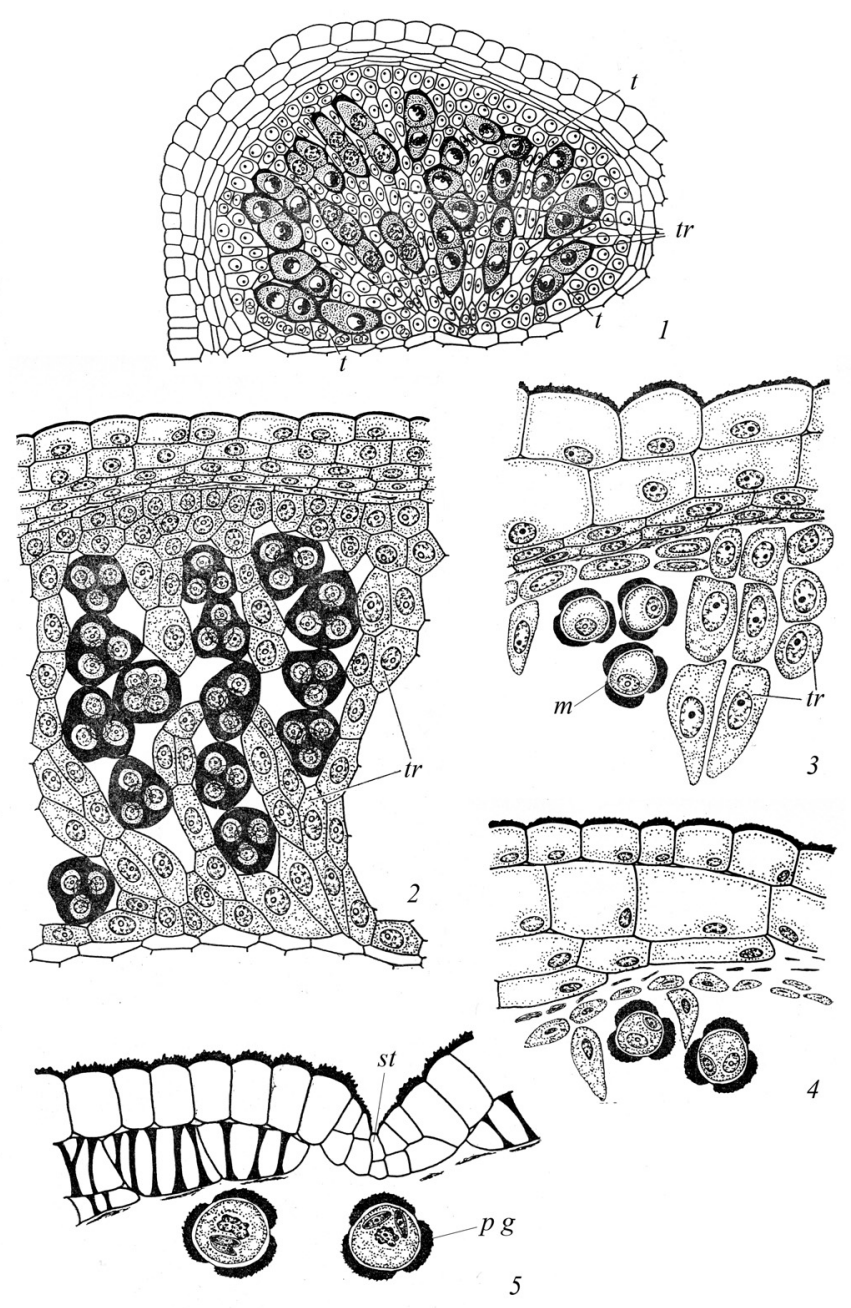

Fig. 2. Structure and development of anther with trabeculae in Gentiana lutea L. (Gentianaceae) (Shamrov, 1986); typical parietal tapetum. 1 - formation of microsporangium wall and trabeculae at the stage of microsporocytes, 2 - structure of wall layers and trabeculae at the tetrad microspore stage, 3, 4 - disappearance of cell walls in tapetum and changes in its structure at the stages of vacuolised microspores (3) and two-celled pollen grains (4), 5 - anther wall in the stomium region before the dehiscence. $m$ - microspore, $p g-$ pollen grain, st - stomium, $t-$ tapetum, $t r$ - trabecula.

ing to Balsaminaceae and Onagraceae (Venkateswarlu and Lakshminarayana, 1957; Steffen and Landmann, 1958; Narayana, 1963).

Authors who study tapetum use different terms, which sometimes contradict each other. At first (Goebel, 1905), there were proposed two types of tapetum (secretory and amoeboid). Cells of secretory tapetum persist and in the amoeboid type the cell walls disintegrate, and protoplasts fuse forming coenocyte plasmodium. Some authors recommend to emphasise the periplasmodial type, replacing the amoeboid type (Tischler, 1915; Claussen, 1927; Echlin, 1971). They discern typical and false subtypes of periplasmodium (Tischler, 1915). Depending on the time of periplasmodium invasion into the locule, four variations can be distinguished: 1, 2 - forming during the first division of meiosis (Sparganium -1) or the second one (Triglochin 2) among the microsporocytes undergoing division, 3 - at 
the stage of tetrads (Butomus), and 4 - after tetrad disintegration among the microspores (Sagittaria) (Claussen, 1927). Carniel $(1961 ; 1963)$ distinguished cellular uninuclear tapetum, cellular polynuclear tapetum and plasmodial tapetum with a large number of nuclei. There is also the third transitional type of tapetum - invasive, or nonsyncytial. In Canna, protoplasts arise after disintegration of the cell walls. At the next stages of microsporogenesis, protoplasts form amoeboid outgrowths but do not fuse (Tiwari and Gunning, 1986). Some authors propose to name secretory tapetum as parietal, and periplasmodial as amoeboid. The types differ by the time of cell fusion, by contact of tapetum cytoplasm with outer surface of pollen grain, and by the longevity in locule. There are variations distinguished within every type (all of them are up to 12) (Pacini et al., 1985; Pacini, 1997; 2010). The classification of tapetum proposed by Kamelina (1981; 1994; 2002; 2009) is of substantial interest. It is based not only on structural features, but on the temporal characteristics when tapetal cells develop. Two types of tapetum are distinguished as well: cellular (secretory) and periplasmodial.

The time of disappearance of the walls between the cells of the tapetum has also been discussed. As it was mentioned, the walls of tapetal cells disintegrate before or during microsporogenesis in the case of the periplasmodial type. A similar process occurs in cellular tapetum as well, but its cell walls disintegrate as a rule at the stage of tetrad decay or at the stage of free microspores. In anther with trabecules, the walls between tapetal cells and trabecules cannot be found, even by special staining methods beginning from the stage of vacuolated microspores. The arisen protoplasts are sharply separated one from another and they exist in this state as late as at the stage of 2-cellular pollen grains.

According to Kamelina (1994), the primary cell walls in cellular tapetum continue to persist up to the stage of microspore tetrads. Their dissolution is followed by the formation of the secondary cell walls containing sporopollenin, and in many cases having orbicules on their inner and radial sides. In many plants tapetum structure does not change further; it modifies solely by lysis of protoplast content. There is only sporopollenin with orbicules on the tapetal plasma membrane retained in mature anthers. This form of cellular tapetum without reorganisation has been recorded in 229 families of dicotyledons plants and 38 families of monocotyledons. Orbicules are spheroid structures. They are found in the anthers of monocotyledonous, dicotyledonous and gymnospermous plants. Their cover consists of sporopollenin. Orbicules are supposed to take part in the following processes: sporopollenin transport; function of hydrophobic layer in the locule providing detachment of pollen grains and pollen dispersal (Pacini et al., 1985; El-Ghazaly, 1989; Pacini, 2010).

There are some other terms in literature to name the cover surrounding every protoplast after the disintegration of tapetal cell walls: "tapetal pellicle", "orbicular coat", and "pellicle". At first, the term "tapetal membrane" appeared in papers on tapetum in gymnosperms (Pettit, 1964) and some Poaceae (Banerjee, 1966). Ogorodnikova (1986; 1990) proposed to name it "sporopollenin coating". Later on, she (Ogorodnikova, 1994), as many other authors, used the term "tapetal membrane" to describe the covering that surrounds completely every cell of secretory tapetum in the post-tetrad period. Extratapetal, or peritapetal membrane, is distinguished on the border of periplasmodial tapetum and the middle layer as well (Heslop-Harrison, 1969; Dickinson, 1970). Therefore, various terms are used in the literature to describe the processes of development of a new coating surrounding tapetum after the destruction of its cell walls. In the opinion of Bhandari (1984), it is better to use the term "tapetal membrane" in this case. It is necessary to specify the sides of protoplast in order to reflect the specificity of the membranes - facing each other (radial membranes), directed inside the locule (inner membranes), or directed to the middle layer (outer membranes).

There are four types of tapetal plasma membrane distinguished in plants with cellular tapetum: I. Pinaceae-type (membrane is represented by fibrillar matter with orbicules embedded in its inner part) - Pinaceae, Alliaceae, Chenopodiaceae, Moraceae, Ruscaceae, Schisandraceae, Simmondsiaceae; II. Rosaceae-type (fibrillar material without orbicules) - Rosaceae, Fabaceae, Linaceae, Polygonaceae; III. Solanaceae-type (tapetal membrane is reticulated, bundle-like, orbicules on the inner membrane) Solanaceae; IV. Poaceae-type (membrane consists of a perforated layer and reticulated interlacing of bundles; orbicules are situated on 1/3 of radial membranes' surfaces, closer to the locule; radial part of membrane fragmentary overlaps the outer one, which is represented by fibrillar material) - Poaceae (Ogorodnikova, 1994).

The new notion, 'tapetum reorganisation', was introduced by Kamelina $(1981 ; 1994)$. It refers to the structural-functional transformation of the cellular tapetum taking place at the beginning of postmeiotic period of anther development. Reorganisation of cellular tapetum is represented by four forms: syncytium (according to Pacini et al., 1985) (previously this form was named as false periplasmodium by Carniel, 1952; 1963; Kamelina, 1981) — protoplasts of tapetal cells unite and fill all the locule (Asteraceae, Caprifoliaceae, Malvaceae, Rubiaceae, Winteraceae, Valerianaceae); amoeboid (by Budell, 1964) — protoplasts enlarge but do not unite (Asteraceae, Berberidaceae, Papaveraceae, Rubiaceae); bordering symplast (by Budell, 1964) - some protoplasts unite remaining in wall-adjacent layer (Berberidaceae); and tapetal tissue (by Kamelina, 1981) — initially everything looks like an amoeboid form, but then secondary cell walls appear and tapetum becomes cellular again. No sporopollenin and orbicules are found in those forms.

In the investigation by Anisimova (2019) it was found out that in four Euphorbia species, tapetum is characterised by cellular structure during premeiotic and meiotic periods. However, the walls between tapetal cells begin to disintegrate at the stages of microspore tetrads in E. seguieriana, 
tetrad decay and microspore formation in E. stepposa, and free microspores in E. iberica and E. petrophila. The process of disappearance of cell walls is accompanied by protrusion of appearing protoplasts inwards to the locule. Reorganisation of the cellular tapetum to the amoeboid type takes place. The protoplasts of tapetal cells remain in a wall-adjacent position where they disintegrate, and their residuals with nuclei exist almost up to anther maturation. Tapetum as a layer with dense cytoplasm persists until the complete union of microsporangia within the thecae. After that cytoplasm becomes vacuolated, protoplasts gradually decrease in size, and their contents lyse. After that, a tapetal membrane forms around every protoplast. The differences in orbicule localisation at tapetal plasma membrane have been described. They usually arise on the inner tangental membrane of tapetum, and in E. seguieriana - on $1 / 3$ of the surface of neighbouring radial ones.

Secretory tapetum as the most frequent among flowering plants (Echlin and Godwin, 1968; Hoefert, 1971; Christensen et al., 1972; Steer, 1977) has been well-studied by electron microscopy (Bhandari, 1984). The ultrastructural studies of tapetal cells in Helleborus foetidus L., Ranunculaceae (Echlin and Godwin, 1968) and Avena sativa L., Poaceae (Steer, 1977) have indicated that the cell walls become thinner at the beginning of meiosis and only the middle cell plate remains on the radial walls at metaphase I. The cell wall partially loses its electron density and demonstrates filamentary structure. At the final stage of dissolution of the tapetal cell walls, pro-orbicular bodies are formed on the inner tapetal membrane, covered with a layer of sporopollenin and associated with endoplasmic reticulum of the protoplast.

These data agree with results of other authors. In Avena sativa L., Secale cereale L. and Triticum aestivum L. (Poaceae), cell walls in tapetum begin to disintegrate at the stage of the middle tetrad of microspores, and after that they loosen. The walls degenerate in the late tetrad stage, but some substances remain on the inner tangental wall. The walls disappear completely and the formation of tapetal membrane with orbicules starts after dissolution of callosic walls of tetrads and appearing of free microspores (Ogorodnikova, 1986; 1990). Chebotaru (1994) studied the genesis of tapetal cells in another species from the same family - Zea mays L. He described five phases in tapetum development: 1 - tapetum differentiation, 2 - divisions of nuclei and their polyploidisation, 3 - increase of physiological-biochemical activity, 4 - onset of way of lytic activity, secretion of sporopollenin precursors and sporopollenin formation, and 5 -"periplasmodisation" of tapetal cells, structural reorganisation of organelles. Phases 1-3 pass on the background of meiosis, phase 4 corresponds to the stage of microspore tetrads, and phase 5 - to the stage of free microspores. "Periplasmodium" moves to the area between developing pollen grains. According to this description, tapetum in $Z$. mays undergoes reorganisation within amoeboid variation.
In Arabidopsis thaliana (L.) Heynh. (Quilichini et al., 2014) tapetal cells differ well from other layers of microsporangium wall before the stage of microspore tetrad. But already at the end of this stage, they produce vacuoles and begin displaying signs of detachment from the adjacent middle layer. Later, the cells become isolated by means of destruction of their walls, and start synthesising the precursors of sporopollenin and bringing those outwards in the cells. Tapetum remains up to the stage of mature 3-celled pollen grains. Data obtained by other authors (Sanders et al., 1999) confirm these facts. It should be noted that it was described earlier (Owen and Makaroff, 1995) that disintegration of tapetal cell walls in A. thaliana starts during meiosis. The inner tangental and radial walls disintegrate in the stage of microspore tetrads. Unlike other species of Brassicaceae family, in A. thaliana the outer tangental walls disintegrate as well. After that, secretion starts from all the sides of the arisen protoplasts.

In Rhododendron luteum Sweet from Ericaceae (Mirgorodskaya and Miroslavov, 2012; Mirgorodskaya et al., 2015) and Ribes nigrum L. from Grossulariaceae (Koteyeva et al., 2015), tapetal cell walls loosen, and exocytosic vesicles appear on the plasmalemma surface at the stage of microspore tetrads. On the periphery of protoplast directed inside the locule, an electron-dense substance accumulates and globules (orbicules) arise at the stage of free microspores. The inner tangental wall remains significantly loosened. Tapetal cells degenerate completely at the stage of mature 2-celled pollen grains. Analysis of the data presented in these papers indicates that reorganisation into amoeboid variation of cellular tapetum is characteristic for the studied species.

Periplasmodial tapetum, after Kamelina (1994), is characterised by formation of coenocyte during the premeiotic and meiotic periods of anther development. It is found among 21 families of monocotyledons. The dissolution of cell walls starts just after formation of the tapetal layer. Like Claussen (1927), she distinguishes three variations in relation to the time of coenocyte formation and intrusion of the originated periplasmodium into the locule: at the stage of microsporocytes (Ruppia), at the stage of microspore tetrads (Potamogeton), and at the stage of tetrad decasy into free microspores (Zannichellia). It should be mentioned that in Zannichellia pedunculata Rchb. (Zannichelliaceae), destruction of tapetal cell walls starts as early as at the stage of diads, and fusion of protoplasts and diffusion of nuclei within the locule occurs at the stage of free microspores (Kamelina and Teryokhin, 1990b). The peritapetal membrane on the boundary between tapetum and the middle layer occurs in plants with a periplasmodial type of tapetum. As a rule, the electron-transparent membrane does not contain orbicules. Only sporopollenin globules are found on it (Heslop-Harrison, 1969; Dickinson, 1970). In some species of Malvaceae, orbicules occur out on the peritapetal membrane of false periplasmodium (Galati et al., 2007). 
The use of electron microscopy partially confirmed the data obtained by Kamelina (1994). It was shown that in Ruppia maritima L. (Ruppiaceae), cell walls in tapetum begin to disintegrate already at the stage of early microsporocytes. Protoplasts fuse, initiating periplasmodium formation. By the beginning of microsporocyte division, the walls tear, and protoplasts intrude into the locule and completely fuse. Periplasmodium becomes highly vacuolated at the stage of microspore tetrads. After the formation of free microspores, tapetum disintegrates completely and its residuals remain on the locule corners (Taylor et al., 2018). The similar performance of tapetum is characteristic for representatives of other families of Alismatales order. Differences relate to the time of protoplast intrusions into the locule: at the stage of meiosis in Juncaginaceae, at the stage of microspore tetrads in Hydrocharitaceae, and after tetrad decay in Scheuchzeria (Scheuchzeriaceae) and Echinodorus (Alismataceae) (Furness and Rudall, 1998; Furness and Banks, 2010).

The problem of discrepancy of principles of the different systems of tapetum types becomes evident when analysing the plants with periplasmodial tapetum type. As it was already noted, in the classification by Kamelina (1994), destruction of cell walls and coenocyte formation take place during premeiotic and meiotic periods, and in the case of reorganisation of cellular tapetum into syncytium, or false periplasmodium — at the beginning of postmeiotic period of anther development. Many authors do not recognise any difference between true and false variations of periplasmodium by the temporal characteristics of tapetum development. For this reason, the examples of processes occurring in tapetum after tetrad decay and leading to destruction of tapetal cell walls and protoplast fusion in Scheuchzeria (Scheuchzeriaceae) and Echinodorus (Alismataceae) (Furness and Banks, 2010), might be referred to syncytium as the form of cellular tapetum reorganisation. However, in Alisma plantago-aquatica L. (Alismataceae), those processes begin during the second division of meiosis, and protrusion of protoplasts into locule - at the stage of free microspores (Nikiticheva, 1990a). A similar observation after tetrad decay was noticed by Claussen (1927) in Sagittaria from the same family. The boundaries dividing premeiotic, meiotic and postmeiotic periods of anther development are not distinct. The processes taking place before meiosis (formation of archesporial and sporogenous cells), during meiosis (microsporogenesis and formation of microspore tetrads), and after meiosis (tetrad disintegration, development of microspores and pollen grains) can be coordinated with the transformations in microsporangium wall layers incompletely. Those transformations can start during one period, and continue or finish during others. Thus, the processes of periplasmodial tapetum reorganisation may start during microsporocyte divisions or at the tetrad stage and may continue at the stage of free microspores. That is why all the variations of tapetum development in Alismataceae can be attributed to the periplasmodial type. It should be added that reorganisation processes in cellular tapetum can also start during the stage of tetrad formation instead of the stage of tetrad decay. Similar observations have been made for tapetum development in Euphorbia genus: at stages of microspore tetrad in E. seguieriana, tetrad decay and free microspores in E. stepposa, and free microspores in E. iberica and E. petrophila (Anisimova, 2019). The same observations have been reported for Avena sativa, Secale cereale and Triticum aestivum, Poaceae (Ogorodnikova, 1986; 1990).

The study of tapetum in Asteraceae is of great interest. An embryological characteristic of this family is that tapetum of the majority of its species is cellular, with reorganisation into an amoeboid type in the postmeiotic period, and in representatives of Arctotideae, Gudelineae, Heliantheae, Vernonieae, Eupatorieae tribes tapetum reorganises into false periplasmodium (Solntseva, 1987). However, secretory tapetum without any reorganisation is described in Vernonia cinerea (L.) Less., V. cinerascens Sch. Bip. (Tiagi and Taimni, 1963), Sonchus oleraceus (L.) L., S. asper (L.) Hill (Walter and Kuta, 1971), and Platycarpha carlinoides Oliv. \& Hiern. (Ahlstrand, 1979). In this case, the cell walls in tapetum disappear after tetrad decay and later, tapetum gradually degenerates. In seven species of Chrysothamnus (Anderson, 1970), tapetum is described as periplasmodial. After the stage of free microspores, the protoplasts protrude into the locule between microspores but do not unite. In Cicerbita alpina (L.) Wallr. (Pullaiach and Lakshmi, 1984), tapetum also is considered as periplasmodial, and the authors presume that the variations of secretory tapetum described before were forms of periplasmodium indeed.

Reorganisation of cellular tapetum into false periplasmodium was found in species of the genus Helianthus. The time of this reorganisation differs. In $H$. annuus L., it was observed in the final stage of tetrade decay, and in $H$. rigidus (Cass.) Desf. at the stage of vacuolated microspores (Toderich, 1988). In H. ciliaris DC and H. tuberosus L., signs of tapetal cell wall destruction were noticed already at the beginning of meiosis (Babro and Voronova, 2018), but nevertheless the authors thought it fit to consider also within the ranks of syncytium.

Previous investigations of $H$. annuus have shown that tapetum in normal plants is initially situated by the periphery of the locule. Two to six nuclei arise in every cell during the first meiotic division. After that, cell walls disappear, and periplasmodium forms; it persists until the stage of late microspores. In contrast to normal plants, in CMS-lines the cell walls in tapetum do not disappear. Tapetum degenerates and microspore tetrads disintegrate after microsporogenesis, while signs of destruction of wall and cytoplasmic organelles in tapetal cells start to be displayed at the beginning of meiosis (Horner, 1977). The type of tapetum development that was found in normal plants of $H$. annuus, is perhaps characteristic for some other species of the Asteraceae family. According to observations of HeslopHarrison (1969), in Ambrosia artemisifolia L., Cosmos bipinnatus Cav., and Tagetes patula L., tapetal cells stay disjuncted in the tangental direction before the tetrad stage. Afterwards, tangental walls become gelatine-like. After the decay of microspore tetrads, periplasmodium forms. A 
membrane arises around tapetal cells and microspores form a kind of a bag ("culture sac"). The membrane is similar to the sporopollenin of pollen grain's exine in its chemical composition.

In Helianthus and plants of some other genera of Asteraceae, periplasmodial tapetum apparently forms in such a mode. In our opinion, the complex of features (early destruction of tapetal cells' walls, fusion of protoplasts and their protrusion into the locule) indicates this. However, in $H$. ciliaris and $H$. tuberosus, protrusion of protoplasts takes place a little later, at the stage of free microspores, as in Alisma plantago-aquatica (Alismataceae) (Nikiticheva, 1990a) and Zannichellia pedunculata (Zannichelliaceae) (Kamelina and Teryokhin, 1990b), rather than at the meiosis stage.

\section{ORIGINAL SYSTEM OF TAPETUM TYPES AND FORMS}

Concluding the analysis of available data on the structure and development of tapetum, we shall propose our opinion on the tapetum diversity in flowering plants. As it was mentioned above, the majority of authors use classifications that include two types of tapetum. Those are: 1. Secretory (cellular, parietal), and 2. Periplasmodium (plasmodial, amoeboid, invasive, intrusive), aside from variations in both types. Our investigation shows that any type of tapetum is secretory, because its cells produce various substances for development of microspores and pollen grains. Usually, at the early stages it is composed of tabular cells with dense cytoplasm, like tissue of a secretory type. Irrespective of tapetum type and the time of destruction start of cell walls, its activity is probably the highest during formation of tetrads and their decay into free microspores. As a rule, it coincides with callase synthesis and subsequent dissolution of callosic walls surrounding tetrads and with the maximum of secretion of sporopollenin precursors (Echlin and Godwin, 1968; Steer, 1977; Chebotaru, 1994; Owen and Makaroff, 1995; Mirgorodskaya et al., 2015). In some plants, cyclisation was observed in tapetum functioning from the completion of meiosis through stages of the early, middle and late microspore tetrads up to the stage of the free vacuolated microspores: Pinus sylvestris L., Pinaceae (Rowley and Walles, 1988), Strelitzia reginae Banks, Strelitziaceae (Kronestedt-Robards and Rowley, 1989), and Nymphaea colorata Peter, Nymphaeaceae (Rowley et al., 1992; Rowley, 1993). This was a basis for separation of the special cyclic-invasive tapetum (Rowley, 1993). Investigations have shown that precursors of sporopollenin accumulate on the primexine already in the tetrads surrounded with callose, and endexine formation starts in microspores and completes in pollen grains.

Any tapetum begins its development with formation of a layer or some layers of cells. The distruction of cell walls occurs in the course of the further development. We regard that it is more preferable for the first type to be named parietal, as it was proposed by Pacini et al. (1985), Pacini
(1997; 2010). Tapetum invades the locule but does not spread inward in this case. The cellular structure remains until microspore tetrad decay. However, as literature data indicate, the destruction of cell walls may start even during meiosis I (Echlin and Godwin, 1968; Steer, 1977; Owen and Makaroff, 1995), during tetrad formation (Ogorodnikova, 1986; 1990; Quilichini et al., 2014), or synchronously with dissolution of callose walls around the tetrad (Chebotaru, 1994). After the destruction of cell walls, orbicules form on tapetal plasma membranes, often on the inner ones. Two forms of parietal tapetum can be distinguished: typical parietal tapetum (protoplasts that form after the disappearance of the cell walls as they gradually break down) (Fig. 3, 1-4; 4, 1-4; 5, 1-4) and amoeboid (they form protrusions inside the microsporangium cavity) (Fig. $6,1-4 ; 7,1-3)$. Usually, the term 'amoeboid' characterises the movement of an animal cell on a substrate, which is realised by intercellular flow of cytoplasm and formation of temporal pseudopodia, as in an amoeba. Formation of amoeboid tapetum involves outgrowths (protrusions) of cells or intrusion, and not fusion of protoplasts. Such understanding was proposed by Budell (1964) following the results of the study of Inula helenium L. He described a special form of tapetum named bordering symplast in Coleus scutellarioides (L.) Benth. and Berberis vulgaris L. However, the bordering symplast is not a form of parietal tapetum, but an intermediate state during the development of periplasmodial tapetum (tapetum is located on the periphery, many protoplasts fuse, but some of them remain independent). The question on the secondary formation of
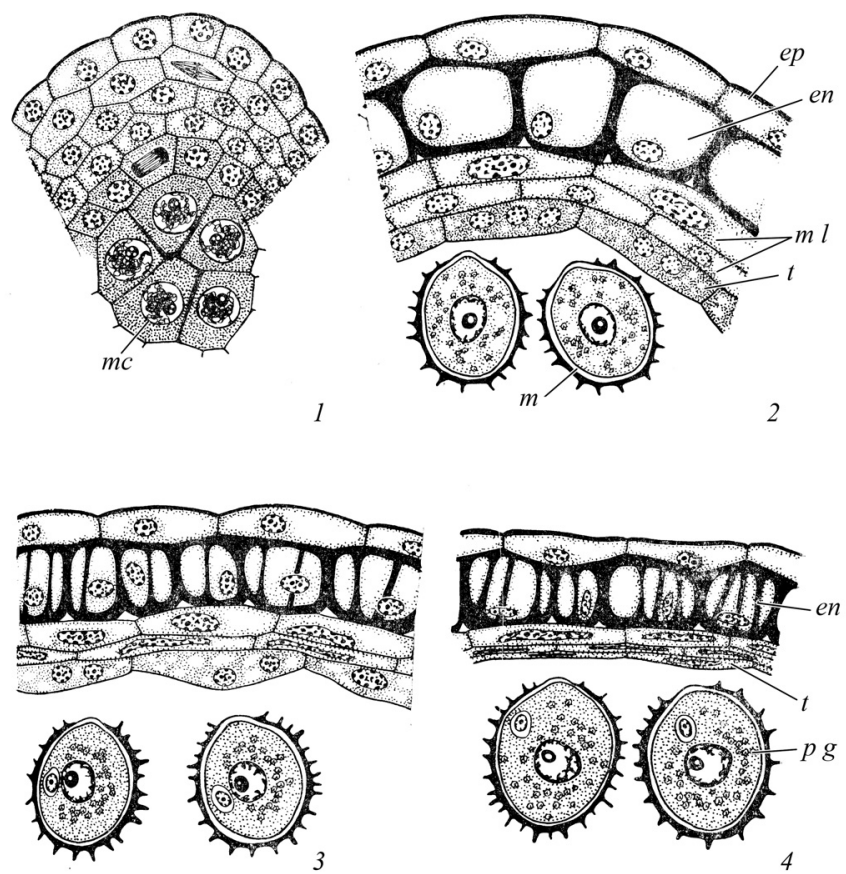

Fig. 3. Cell differentiation and specialisation of wall microsporangium layers in Nuphar lutea (L.) Sm. (Nymphaeaceae) (Shamrov, 2015); typical parietal tapetum. 1 - formation of microsporangium wall at the stage of microsporocytes, 2 - structure of wall layers at the separate microspore stage, 3, 4-disappearance of tapetum cells at the stage of two-celled pollen grains. en - endothecium, ep - epidermis, $m$ - microspore, $m c-$ microsporocyte, $m l$ - middle layer, $p g$ - pollen grain, $t$ - tapetum. 


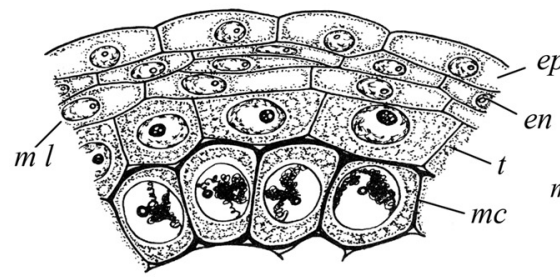

1

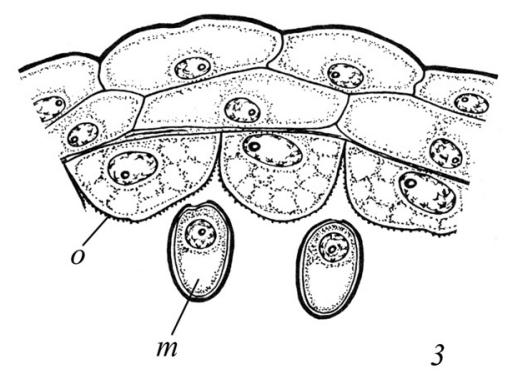

3
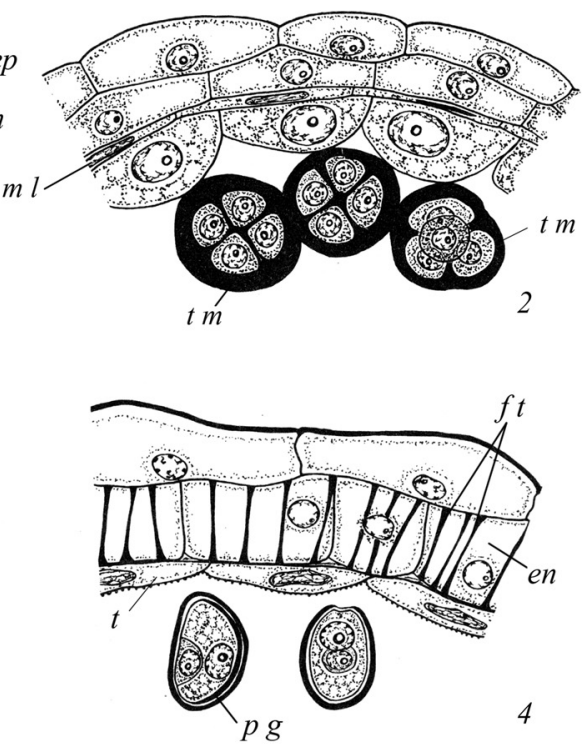

Fig. 4. Cell differentiation and specialisation of wall microsporangium layers in Allium caspium (Pall.) M. Bieb. (Alliaceae) (Shamrov, 2006); ameboid variation of parietal tapetum. 1 - formation of microsporangium wall at the stage of microsporocytes, 2 - structure of wall layers at the stage of microspore tetrads, 3 - disappearance of cell walls in tapetum and changes in its structure at the stage of vacuolised microspores, 4 - disappearance of tapetum cells at the stage of two-celled pollen grains. en - endothecium, ep epidermis, $f t$ - fibrous thickenings, $m-$ microspore, $m c$ - microsporocyte, $m l$ - middle layer, $o$ - orbicules on tapetal membrane, $p g-$ pollen grain, $t$ - tapetum, $t m$ - tetrad of microspores.
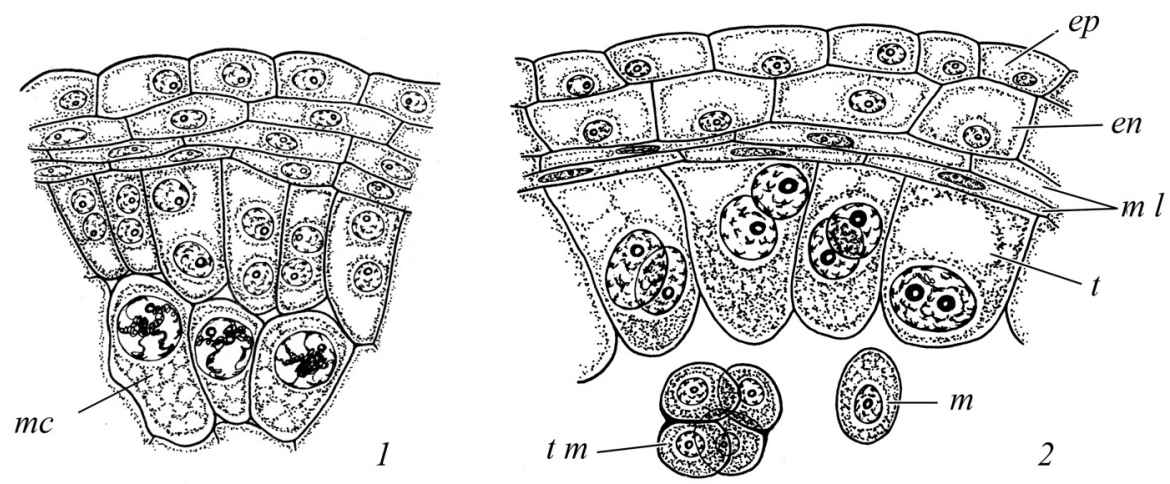

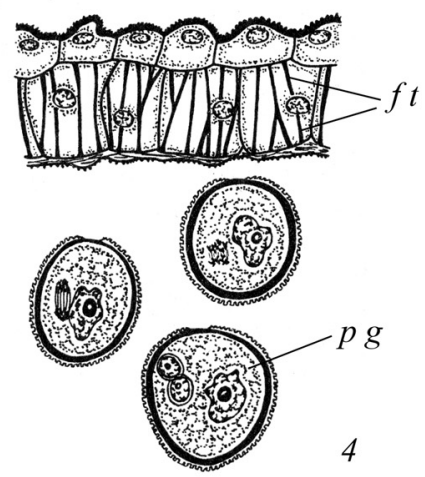

Fig. 5. Development and structure of anther in Hemerocallis citrina Baroni $(1,3,4)$ and $H$. hybrida, Hemerocallidaceae (2) (Shamrov, 1990a); typical parietal tapetum. 1 - formation of microsporangium wall at the stage of microsporocytes, 2 - structure of wall layers at the stage of microspore tetrads, 3, 4-disappearance of cell walls in tapetum and changes in its structure at the stages of vacuolised microspores (3) and two-celled pollen grains (4). en - endothecium, ep - epidermis, $f t$ - fibrous thickenings, $m$ - microspore, $m c-$ microsporocyte, $m$ $l$ - middle layer, $o$ - orbicules on tapetal membrane, $p$ - pollenkitt, $p g-$ pollen grain, $t-$ tapetum, $t m$ - tetrad of microspores. tapetal tissue in the locule (Kamelina, 1981; 1994) needs further investigation. Invasive or insyncytial types (Tiwari and Gunning, 1986) correspond to variation of amoeboid tapetum. Orbicule formation is possible in the course of development.

It is preferable to name the second type of tapetum as periplasmodial. It arises as a result of the fusion of cells' protoplasts. Cytoplasm and nuclei of the periplasmodial tapetum are both located between the developing microspores or pollen grains and contact the inner layers of the microsporangium wall. Earlier, in the course of tapetum development, some authors have described the so-called true (according to Carniel, 1963), but also false (Carniel, 1952;
1963; Kamelina, 1981) periplasmodium, or syncytium (Pacini, 1997; 2010), being considered in numerous investigations as a form of cellular tapetum. The meaning of the term 'syncytium' does not proclaim completely the similarity of the true and false periplasmodia genesis. Firstly, the semantics of the term 'syncytium' (Greek. syn - together, kitos - cell) shows the remaining association between the divided cells rather than between the nuclei forming in the case of false periplasmodium. This term was also used incorrectly in describing nuclear endosperm in the coenocyte stage in Hordeum vulgare L. (Poaceae) (Sreenivasulu and Wobus, 2013) and Arabidopsis thaliana (Brassicaceae) (Guo et al., 2018). Typical syncytium is known as a form of mesenchymatous tissue in animals. In humans, syncytium 

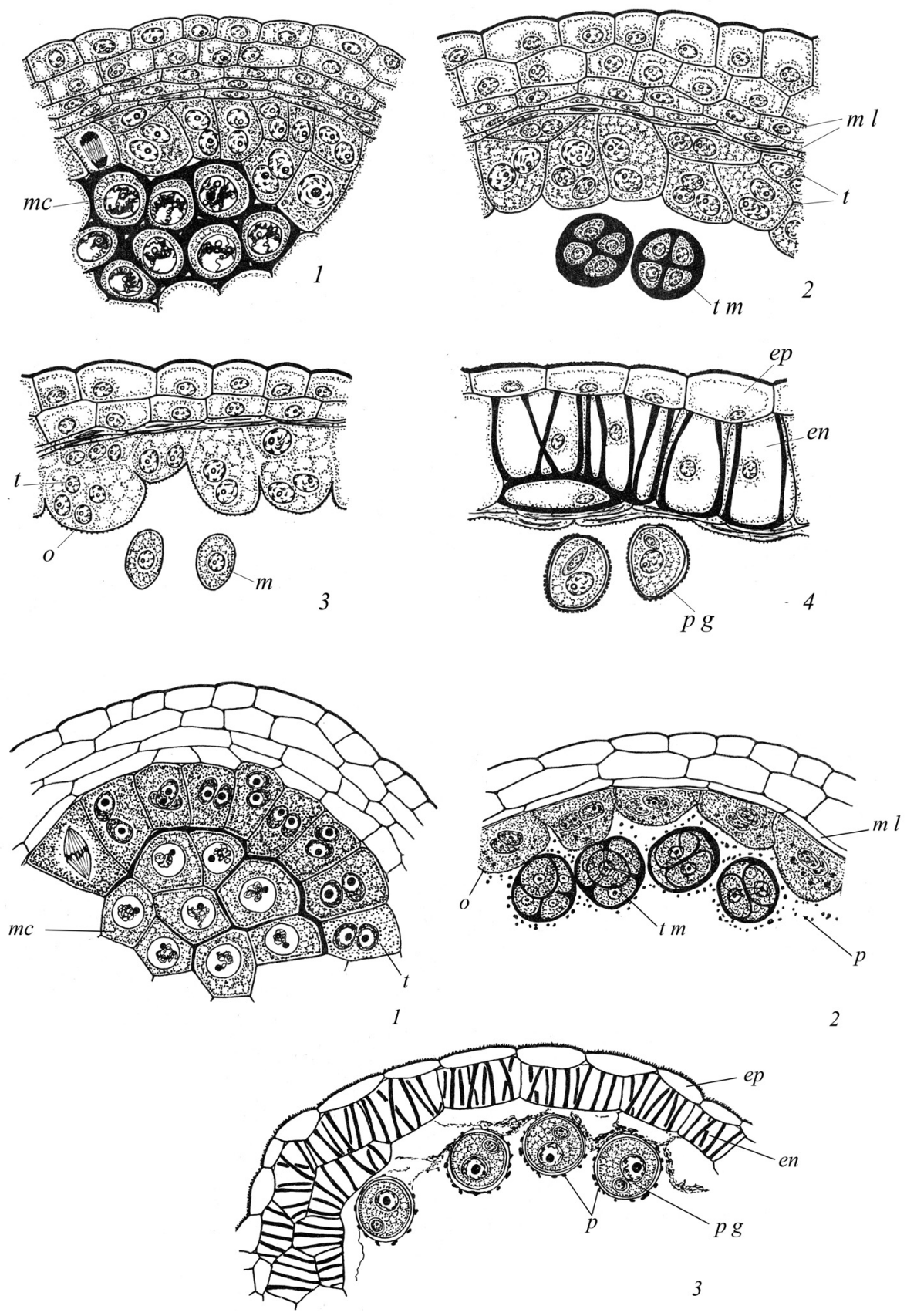

Fig. 6. Stages of anther development in Veratrum lobelianum Bernh. (Melanthiaceae) (Shamrov, 1990b); ameboid variation of parietal tapetum. 1 - formation of microsporangium wall at the stage of microsporocytes, 2 - structure of wall layers at the stage of microspore tetrads, tapetal cells form protrusions inside the microsporangium cavity, 3 - disappearance of cell walls in tapetum at the stage of vacuolised microspores, 4 - wall of the mature anther. en - endothecium, ep - epidermis, $m$ - microspore, $m c-$ microsporocyte, $m l-$ middle layer, $o$ - orbicule, $p g$ - pollen grain, $t-$ tapetum, $t m$ - tetrad of microspores.
Fig. 7. Stages of anther development in Cordyline terminalis (L.) Kunth (Dracaenaceae) (after Anisimova, 1990); ameboid variation of parietal tapetum. 1 - formation of microsporangium wall at the stage of microsporocytes, 2 - structure of wall layers at the stage of microspore tetrads, tapetal cells form protrusions inside the microsporangium cavity, 3 - disappearance of cell walls in tapetum and changes in its structure at the stage of two-celled pollen grains (4). en - endothecium, ep - epidermis, $m c$ - microsporocyte, $m l$ - middle layer, $o-$ orbicules on tapetal membrane, $p$ - pollenkitt, $p$ $g$ - pollen grain, $t$ - tapetum, $t m$ - tetrad of microspores. forms during meiosis (spermatogonial divisions). Cytokinesis does not complete and the cells appear to be joined together with cytoplasmic bridges. Clones of interconnected cells generate as a result of the further divisions (Gilbert, 2003; Danilov and Borovaya, 2018). The phenomenon of the complete protoplasts fusion and the absence of cytoplasmic bridges make it possible to assemble all the present forms within the periplasmodial type. Two forms of periplasmodial tapetum can be distinguished: combining and invasing of protoplasts into the cavity of microsporangium (form 1 - typical periplasmodial tapetum) (Fig. $8,1-6)$, almost or partly fusion of protoplasts, which do not organise the invasions and maintain their initial position (form 2 - bordering symplast) (Fig. 8, 7, 8). Extratapetal, or peritapetal plasma membrane forms in the periplasmodial tapetum; as a rule it contains sporopollenine globules. According to Kamelina (1994), periplasmodial tapetum is in- herent only to monocotyledons, the number of families of which is 21 . However, taking into account dicotyledons, in which the presence of syncytium, as a form of secretory tapetum, has been ascertained, the number of families with periplasmodial tapetum increases and amounts to about 40 families with an equal ratio of dicotyledons and monocotyledons.

As we noted earlier, parietal tapetum has been recorded in 229 families of dicotyledons and 38 families of monocotyledons. Periplasmodial tapetum was observed in almost 40 families of dicotyledons and monocotyledons. This type of tapetum is best represented in monocotyledons, especially in the subclass Alismatidae. In more than 13 families of monocotyledons and 20 families of dicotyledons, this embryological trait has been studied extremely fragmentarily. In these families only some species and genera have 

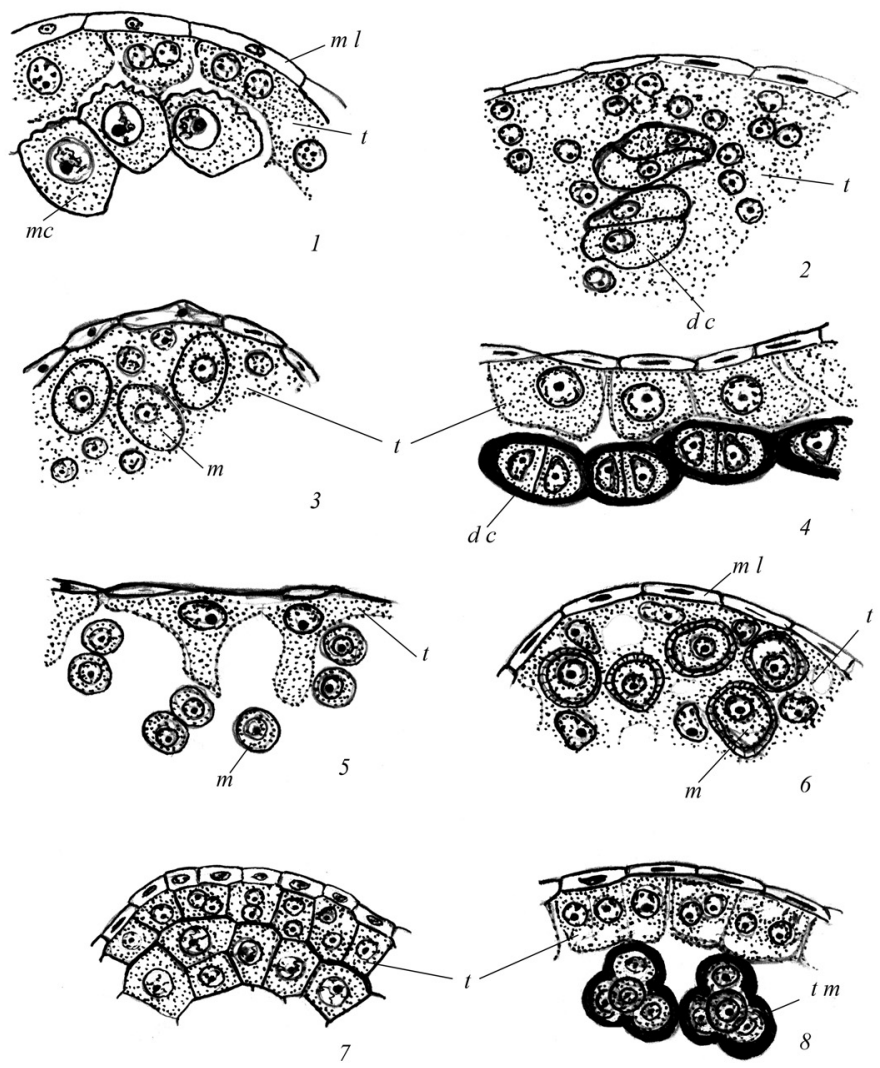

Fig. 8. Forms of periplasmodial tapetum (after literature data, schematic). 1-8 - stages of anther development. 1-6 - typical periplasmodial tapetum: 1-3 - Ruppia brachypus J. Gay (Rupppiaceae), cell walls of tapetum begin to break down at the start of meiosis (1); 4-6 - Alisma plantago-aquatica L. (Alismataceae), cell walls of tapetum begin to disintegrate after 1st meiosis divisions of microsporocytes (4); 7, 8 - bordering symplast of periplasmodial tapetum in Coleus scutellarioides (L.) Benth. (Lamiaceae), cell walls of tapetum begin to break down at the tetrad microspore stage. 1-3 - after Kamelina and Teryokhin, 1990; 4-6 - after Nikiticheva, 1990; 7, 8 - after Budell, 1964. $d c$ - dyad of cells, $m$ - microspore, $m c-$ microsporocyte, $m l$ - middle layer, $t$ - tapetum, $t m$ - tetrad of microspores.

been studied. The appearance of some variants of the tapetum in flowering plants probably occurred many times, as evidenced by the distribution of its types and forms according to the phylogenetic system. Therefore, the feature of the presence of parietal or periplasmodial tapetum cannot be used in the interpretation of phylogenetic relationships. However, in some monocotyledons the presence of this trait in most representatives emphasises their similarity both within the subclass Alismatidae and the orders included in this subclass. All members of Alismatidae exhibit a periplasmodial tapetum, and this type of tapetum is hypothesised to be a synapomorphy of Alismatales (Furness and Rudall, 1998; Furness and Banks, 2010), which is subsequently restricted to Alismataceae, Butomaceae and Hydrocharitaceae, which compose their own clade (Les and Tippery, 2013). Intrusion of the anther locule before or during early meiosis occurs in Cymodoceaceae (Furness and Banks, 2010). The same was observed in Ruppia maritima L. (Taylor et al., 2018), which supports the close relationship of Cymodoceaceae and Ruppiaceae in the Cymodo- ceaea complex. This complex plus the families Aponogetonaceae, Juncaginaceae, Maundiaceae, Potamogetonaceae, Scheuchzeriaceae, and Zosteraceae form a clade that is recognised as Potamogetonales. Despite the fact that some families of the order Potamogetonales are poorly studied (Maundiaceae, Zosteraceae), representatives of other families show uniformity in the dynamics of development and structure of the periplasmodial tapetum - destruction of cell walls at the beginning of meiosis, formation of protoplast outgrowths inside the locule at the end of meiosis, and fusion of protoplasts at the stage of tetrad microspores (Kamelina, 1990; Nikiticheva, 1990b; 1990c; Nikiticheva and Proskurina, 1990). These facts confirm the opinion that in members of order Potamogetonales, the specifity of tapetum development can be considered as a synapomorphy. Thus, most representatives of the Alismatidae subclass are characterised by a periplasmodial tapetum, which can be considered as a synapomorphic character.

\section{CONCLUSIONS AND FURTHER PROSPECTS}

Authors who studied tapetum have used different terms, which sometimes contradict each other. Most often, the cellular (secretory) and plasmodial, or periplasmodial types of tapetum are distinguished. Analysis of the available data showed that any type of tapetum is secretory, because its cells produce various substances for development of microspores and pollen grains. The time of disappearance of the walls between the cells of the tapetum is also discussed. The walls of typical periplasmodial tapetal cells may disintegrate before, during meiosis, and even after microsporogenesis in false periplasmodium. A similar process occurs in cellular tapetum. Its cell walls disintegrate not only at the stage of free microspores, as has been often noted in the literature. Ultrastructual studies of tapetal cells have indicated that the cell walls become thinner at the beginning of meiosis and only the middle cell plate remains on the radial walls at metaphase I. These temporal parameters in any type of tapetum can be used when analyzing the time of appearance of taxa. The earlier ontogenetic time of the appearance of characters probably indicates their basal position when comparing closely related taxa. Based on the analysis of literature and our own data, we proposed a new look at the typification of types and forms of the tapetum, drawing attention to the semantics of the distinguished types and forms. Data on the diversity and structure of the tapetum, like any other characters, are used to clarify the position of taxa on the phylogenetic tree.

\section{ACKNOWLEDGEMENTS}

The research was carried out within the framework of the institutional research projects "Structural-functional bases of development and adaptation in higher plants", "Polyvariation of morphogenetic developmental programmes of plant reproductive structures, natural and artificial models of their realisation" (Komarov Botanical Institute of RAS, state registration $N$ AAAA-A18-118031690084-9 and 
N AAAA-A18-118051590112-8 - collecting of materials and description of study results), and "Study and conservation of plant biological diversity" (Herzen State Pedagogical University of Russia, N 34.29.01 - discussion of obtained results).

\section{REFERENCES}

Ahlstrand, L. (1979). Embryology of Actotideae-Gundeliinae (Compositae). Bot. Notiser, 132 (3), 377-381.

Anderson, L. C. (1970). Embryology of Chrysothamnus (Astereae, Compositae). Madrono, 20 (7), 337-342.

Anisimova, G. M. (1990). (Dracaenaceae) family. In: Comparative Embryology of Flowering Plants. Butomaceae-Lemnaceae. Nauka, Leningrad [Анисимова, Г. М. Семейство Dracaenaceae. В кн.: Сравнительная эмбриология иветковых растений. Bиtотасеае-Lетпасеае. Наука Ленинград], pp. 124-127 (in Russian).

Anisimova, G. M. (2016). Anther structure, microsporogenesis and polen grain in Kalanchoe nyikae (Crassulaceae). Botanicheskii Zhurnal [Анисимова, Г. М. Строение пыльника, микроспорогенез и пыльцевое зерно у Kalanchoe nyikae (Crassulaceae). Ботанический журнал], 101 (12), 1378-1389 (in Russian).

Anisimova, G. M. (2019). Anther structure and development in some species of subgenera Esula of genera Euphorbia (Euphorbiaceae). Botanicheskii Zhurnal [Анисимова, Г. М. Строение и развитие пыльника некоторых видов подрода Esula рода Euphorbia (Euphorbiaceae). Ботанический журнал], 104 (2), 3-22 (in Russian).

Babro, A. A., Voronova, O. N. (2018). The development of male reproductive structures in wild species of sunflower Helianthus ciliaris and $H$. tuberosus (Asteraceae). Botanicheskii Zhurnal [Бабро, А. А., Воронова, О. Н. Развитие мужских репродуктивных структур у Helianthus ciliaris и H. tuberosus (Asteraceae). Ботанический журнал], 103 (9), 1093-1108 (in Russian).

Banerjee, U. C. (1967). Ultrastructure of tapetal membranes in grasses. Grana Palyn., 7 (2-3), 365-377.

Batygina, T. B., Teryokhin, E. S, Alimova, G. K., Yakovlev, M. S. (1963). Genesis of male sporangia in the families of Gramineae and Ericaceae. Botanicheskii Zhurnal [Батыгина, Т. Б., Терехин, Э. С., Алимова, Г. К., Яковлев, М. С. Генезис мужских спорангиев Gramineae и Ericaceae. Ботанический журнал], 48 (8), 1108-1120 (in Russian).

Bhandari, N. N. (1984). Microsporangium. In: Embryology of Angiosperms. Springer-Verleg, Berlin, Heidelberg, pp. 53-121.

Budell, B. (1964). Untersuchungen der Antherenentwicklung einiger Blütenpflanzen. Zeitschr. Bot., 52 (1), 1-28.

Carniel, K. (1952). Das Verhalten der Kerne im Tapetum der Angiospermen mit besonderer Berücksichung von Endomitosen und sogenannten Endomitosen. Õsterr. Bot. Zeit., 99 (3), 318-363.

Carniel, K. (1961). Das Antherentapetum von Zea mays. Õsterr. Bot. Zeit., 108 (1), 89-96

Carniel, K. (1963). Das Antherentapetum. Õsterr. Bot. Zeit., 110 (2-3), $145-176$.

Chauhan, S. V. S. (1977). Dual role of the tapetum. Curr. Sci., 46 (19), 674-675.

Chauhan, S. V. S. (1979). Development of endothecium in relation to tapetal behaviour in some male sterile plants. Phytomorphology, 29 (3-4), $245-251$

Chauhan, S. V. S., Gupta, H. K. (2006). Suppression of endothecium development by malformed tapetum in the anthers of chemically treated Lens culinaris. Phytomorphology, 56 (1-2), 10-16.

Chebotaru, A. A. (1994). Tapetum: ultrastructural aspects. In: Embryology of Flowering Plants. Terminology and Concepts. St. Petersburg [Чеботарь, А. А. Тапетум. Ультраструктурные аспекты. В кн.: Эмбриология иветковых растений. Терминология и концепиии. Санкт-Петербург], pp. 52-56 (in Russian)

Christensen, J. E., Horner, H. T., Lersten, N. R. (1972). Pollen wall and tapetal orbicular wall development in Sorghum bicolor (Gramineae). Amer. J. Bot., 59, 43-58.

Claussen, P. (1927). Über das Verhalten des Antherentapetum bei einiger Monokotylen und Ranales. Bot. Archiv Kõnigsberg, 18 (1-3), 1-27.

Danilov, R. K., Borovaya, T. G. (2018). Histology, embryology, cytology. St. Petersburg [Данилов, Р. К., Боровая, Т. Г. Гистология, эмбриология, цитология. Санкт-Петербург]. 520 pp. (in Russian).

Davis, G. L. (1966). Systematic Embryology of Angiosperms. John Wiley and Sons, New York etc. 528 pp.

Dickinson, H. G. (1970). The fine structure of a peritapetal membrane investing the microsporangium of Pinus banksiana. New Phytologist, 69 (4), 1065-1068.

Echlin, P. (1971). The role of the tapetum in microsporogenesis of angiosperms. In: Pollen Development and Physiology. Butterworth-Heinemann, London, pp. 41-62.

Echlin, P., Godwin, H. (1968). The ultrastructure and ontogeny of pollen in Helleborus foetidus L. I. The development of the tapetum and Ubish bodies. J. Cell Sci., 3, 161-174.

El-Ghazaly, G. (1989). Pollen and orbicule morphology of some Euphorbia species. Grana, 28, 234-259.

El-Ghazaly, G. (2002). Tapetum and orbicules (Ubish bodies). In: Embryology of Flowering Plants. Terminology and Concepts. Vol. 1. Enfield (NH), USA, Plymouth, UK, pp. 20-21.

Fei, J., Tan, S., Zhang, F., Hua, L., Liao, Y., Fang, W., Chen, F., Teng, N. (2016). Morphological and physiological differences between dehiscent and indehiscent anthers of Chrysanthemum morifolium. J. Plant Res., 129 (6), 1069-1082.

Furness, C. A., Banks, H. (2010). Pollen evolution in the early-divergent monocot order Alismatales. Int. J. Plant Sci., 171 (3), 713-739.

Furness, C. A., Rudall, P. J. (1998). The tapetum and systematics in monocotyledons. Bot. Rev., 64, 201-239.

Furness, C. A., Rudall, P. J. (2001). The tapetum in basal angiosperms: early diversity. Int. J. Plant Sci., 162 (2), 375-392.

Galati, B. G., Monacci, F., Gotelli, M. M., Rosenfeldt, S. (2007). Pollen, tapetum and orbicule development in Modiolastrum malvifolium (Malvaceae). Ann. Bot., 99 (4), 755-763.

Gilbert, S. F. (2003). Developmental Biology. Sunderland, Massachusetts. $850 \mathrm{pp}$.

Goebel, K. (1905). Organography of Plants. Vol. 2. Clarendon Press, Oxford. $707 \mathrm{pp}$

Guo, L., Jiang, L., Lu, X.-L., Liu, C.-M. (2018). Anaphase promoting complex/cyclosome-mediated cyclin B1 degradation is critical for cell cycle synchronization in syncytial endosperms. J. Integr. Plant Biol., 60 (6), $448-454$.

Heslop-Harrison, J. (1969). An acetolysis-resistant membrane investing tapetum and sporogenous tissue in the anthers of certain Compositae Canad. J. Bot., 47 (4), 541-542.

Hoefert, L. L. (1971). Ultrastructure of the tapetal cell ontogeny in Beta. Protoplasma, 73, 397-406.

Horner, H. T. (1977). A comparative light- and microscopic study of microsporogenesis in male-fertile and cytoplasmic male-sterile sunflower (Helianthus annuus). Amer. J. Bot., 64 (6), 745-759.

Kamelina, O. P. (1981). Anther. In: Comparative Embryology of Flowering Plants. Winteraceae-Juglandaceae. Nauka, Leningrad [Камелина, О. П. Пыльник. В кн.: Сравнительная эмбриология иветковых растений. Winteraceae-Juglandaceae. Наука, Ленинград], pp. 18-21) (in Russian). 
Kamelina, O. P. (1985). Escalloniaceae family. In: Comparative Embryology of Flowering Plants. Brunellaceae-Tremandraceae. Nauka, Leningrad [Камелина, О. П. Семейство Escalloniaceae. В кн.: Сравнительная эмбриология иветковых растений. Brunellaceae-Tremandraceae. Наука, Ленинград], pp. 9-14 (in Russian).

Kamelina, O. P. (1990). Potamogetonaceae family. In: Comparative Embryology of Flowering Plants. Butomaceae-Lemnaceae. Nauka, Leningrad [Камелина, О. П. 1990. Семейство Potamogetonaceae. В кн.: Сравнительная эмбриология изветковых растений. BиtотасеаеLemnaceae. Наука, Ленинград], pp. 34-39 (in Russian).

Kamelina, O. P. (1994). A new approach to the classification of tapetum types. In: Embryologyof Flowering Plants. Terminology and concepts. Vol. 1. St. Petersburg [Камелина, О. П. Новый подход к классификации типов тапетума. В кн.: Эмбриология иветковых растений. Терминология и кониеепиии. Санкт-Петербург. Т. 1], pp. 56-60) (in Russian).

Kamelina, O. P. (2002). New approach to the classification of tapetum types. In: Embryology of Flowering Plants. Terminology and Concepts. Vol. 1. Enfield (NH), USA- Plymouth, UK. pp. 28-32.

Kamelina, O. P. (2009). Systematic Embryology of Flowering Plants. Dicotyledons. ARTIKA, Barnaul [Камелина, О. П. Систематическая эмбриология иветковых растений. Двудольные. АРТИКА, Барнаул]. 501 pp. (in Russian).

Kamelina, O. P., Teryokhin, E. S. (1990a). Ruppiaceae family. In: Comparative Embryology of Flowering Plants. Butomaceae-Lemnaceae. Nauka, Leningrad [Камелина, О. П., Терехин, Э. С. Семейство Ruppiaceae. В кн.: Сравнительная эмбриология иветковых растений. ButoтасеаеLemnaceae. Наука, Ленинград], pp. 39-44 (in Russian).

Kamelina, O. P., Teryokhin, E. S. (1990b). Zannichelliaceae family. In: Comparative Embryology of Flowering Plants. Butomaceae-Lemnaceae. Nauka, Leningrad [Камелина, О. П., Терехин, Э. С. Семейство Zannichelliaceae. В кн.: Сравнительная эмбриология иветковых растений. Butomaceae-Lemпасеае. Наука, Ленинград], pp. 44-50 (in Russian).

Koteyeva, N. K., Mirgorodskaya, O. E, Bulisheva, M. M, Miroslavov, E. A. (2015). Pollendevelopment in Ribes nigrum (Grossulariaceae) in relation to the low temperature period. Botanicheskii Zhurnal [Котеева, Н. К., Миргородская, О. Е., Булышева, М. М., Мирославов, Е.А. Формирование пыльцы Ribes nigrum (Grossulariaceae) в связи с периодом пониженных температур. Ботанический журнал], 100 (10), 1001-1014 (in Russian).

Kronestedt-Robards, E. C., Rowley, J. R. (1989). Pollen grain development and tapetal changes in Strelitzia reginae (Strelitziaceae). Amer. J. Bot., 76 (7), 856-870.

Les, D. H., Tippery, N. P. (2013). In time and with water ... the systematics of alismatid monocotyledons. In: Early Events in Monocot Evolution. Cambridge, pp. 118-164.

Mirgorodskaya, O. E., Miroslavov, E. A. (2012). Microsporogenesis and tapetal cells development in Rhododendron luteum (Ericaceae). Botanicheskii Zhurnal [Миргородская, О. Е., Мирославов, Е. А. Микроспорогенез и развитие клеток тапетума Rhododendron luteum (Ericaceae). Ботанический журнал], 97 (1), 356-365) (in Russian).

Mirgorodskaya, O. E., Koteyeva, N. K., Volchanskaya, A. V., Miroslavov, E. A. (2015). Pollen development in Rhododendron in relation to winter dormancy and bloom time. Protoplasma, 252, 1313-1323.

Narayana, L. L. (1963). Contributions to the embryology of Balsaminaceae. J. Ind. Bot. Soc., 42 (1), 102-109.

Nikiticheva, Z. I. (1990a). Alismataceae family. In: Comparative Embryology of Flowering Plants. Butomaceae-Lemnaceae. Nauka, Leningrad [Никитичева, 3. И. Семейство Alismataceae. В кн.: Сравнительная эмбриология цветковых растений. Butomaceae-Lemnaceae. Наука, Ленинград], pp. 16-20 (in Russian).

Nikiticheva, Z. I. (1990b). Aponogetonaceae family. In: Comparative Embryology of Flowering Plants. Butomaceae-Lemnaceae. Nauka, Leningrad [Никитичева, 3. И. Семейство Aponogetonaceae. В кн.:
Сравнительная эмбриология иветковых растений. ButoтасеаеLeтпасеае. Наука, Ленинград], pp. 24-25 (in Russian).

Nikiticheva, Z. I. (1990c). Scheuchzeriaceae family. In: Comparative Embryology of Flowering Plants. Butomaceae-Lemnaceae. Nauka, Leningrad [Никитичева, 3. И. Семейство Scheuchzeriaceae. В кн.: Сравнительная эмбриология изветковых растений. BиtотасеаеLeтпасеае. Наука, Ленинград], pp. 26-28 (in Russian).

Nikiticheva, Z. I., Proskurina, O. B. (1990). Juncaginaceae family. In: Comparative Embryology of Flowering Plants. Butomaceae-Lemnaceae. Nauka, Leningrad [Никитичева, 3. И., Проскурина, О. Б. Семейство Juncaginaceae. В кн.: Сравнительная эмбриология иветковых растений. Витотасеае-Lетпасеае. Наука, Ленинград], pp. 28-34 (in Russian).

Ogorodnikova, V. F. (1986). The genesis and ultrastructure of the sporopollenin wall of tapetal cells in grasses. Botanicheskii Zhurnal [Огородникова, В. Ф. Генезис и ультраструктура спорополлениновой оболочки клеток тапетума злаков. Ботанический журнал], 71 (10), 1366-1371 (in Russian).

Ogorodnikova, V. F. (1990). The dynamics of cell organelle ultrastructure in tapetum of Triticumaestivum (Poaceae). Botanicheskii Zhurnal [Огородникова, В. Ф. Динамика ультраструктуры клеточных органелл тапетума Triticum aestivum (Роасеае). Ботанический журнал], 75 (2), 186-192 (in Russian).

Ogorodnikova, V. F. (1994). Tapetal membrane. In: Embryology of Flowering Plants. Terminology and Concepts. Vol. 1. St. Petersburg [Огородникова, В. Ф. Тапетальная мембрана. В кн.: Эмбриология цзветковых растений. Терминология и концепции. Т. 1. СанктПетербург], pp. 49-50 (in Russian).

Owen, H. A., Makaroff, C. A. (1995). Ultrastructure of microsporogenesis and microgametogenesis in Arabidopsis thaliana (L.) Heynh., ecotype Wassilewskaja (Brassicaceae). Protoplasma, 185, 7-21.

Pacini, E. (1997). Tapetum character states: Analytical keys for tapetum types and activities. Canad. J. Bot., 75 (9), 1448-1459.

Pacini, E. (2010). Relationships between tapetum, loculus, and pollen during development. Int. J. Plant Sci., 171 (1), 1-11.

Pacini, E., Franchi, G. G., Hesse, M. (1985). The tapetum: Its form, function and possible phylogeny in Embryophyta. Plant Sys. Evol., 149 (3-4), $155-185$.

Pettit, J. M. (1966). A new interpretation of the structure of the megaspore membrane in somegymnospermous ovules. J. Linn. Soc. London (Bot.), 59 (379), 253-263.

Pullaiach, T., Swarajya Lakshmi, P. L. (1984). A contribution to the embryology of Cicerbitaalpina (Linn.) Wallr. Proc. Indian Acad. Sci. (Plant Sci.), 93 (4), 437-443.

Quilichini, T. D., Douglas, C.J., Samuels, A. L. (2014). New views of tapetum ultrastructure and pollen exine development in Arabidopsis thaliana. Ann. Bot., 114 (6), 1189-1201.

Rowley, J. R. (1993). Cycles of hyperactivity in tapetal cells. Pl. Syst. Evol. (Suppl.), 7, 23-37.

Rowley, J. R., Gabarayeva, N. I., Walles, B. (1992). Cyclic invasion of tapetal cells into loculi during microspore development in Nymphaea colorata (Nymphaeaceae). Amer. J. Bot., 79 (7), 801-808.

Rowley, J. R., Walles, B. (1988). Cell differentiation in microsporangia of Pinus sylvestris: Diplotene and diffuse stage. Ann. Sci. Nat. Paris. Ser. 13, 9, 1-28.

Sanders, P. M., Bui, A. Q., Weterings, K. (1999). Anther developmental defects in Arabidopsis thaliana male-sterile mutants. Sex. Plant Reprod., 11, 297-322.

Shamrov, I. I. (1986). Anther development in Gentiana lutea (Gentianaceae). Botanicheskii Zhurnal [Шамров, И. И. Развитие пыльника у Gentiana lutea (Gentianaceae). Ботанический журнал], 71 (6), 733-739 (in Russian). 
Shamrov, I. I. (1988). Structure of septate anthers in some flowering plants. Ann. Sci. l'Univ. Reims., 23, 68-70.

Shamrov, I. I. (1990a). Hemerocallidaceae family. In: Comparative Embryology of Flowering Plants. Butomaceae-Lemnaceae. Nauka, Leningrad [Шамров, И. И. Семейство Неmerocallidaceae. В кн: Сравнительная эмбриология иветковых растений. Bиtотасеае-Lетпасеае. Наука, Ленинград], pp. 83-87 (in Russian).

Shamrov, I. I. (1990b). Melanthiaceae family. In: Comparative embryology of Flowering Plants. Butomaceae-Lemnaceae. Nauka, Leningrad [Шамров, И. И. Семейство Melanthiaceae. В кн: Сравнительная эмбриология иветковых растений. Bиtотасеае-Lетпасеае. Наука, Ленинград], pp. 59-63 (in Russian).

Shamrov, I. I. (2006). Morphological nature of ovule and its evolutionary lineages in flowering plants. Botanicheskii Zhurnal [Шамров, И. И. Морфологическая природа семязачатка и эволюционные тенденции его развития у цветковых растений. Ботанический журнал], 91 (11), 1601-1636 (in Russian).

Shamrov, I. I. (2008a). Ovule of Flowering Plants: Structure, Functions, Origin. Moscow [Шамров, И. И. Семязачаток цветковых растений: строение, функции, происхождение. Москва]. 356 pp. (in Russian).

Shamrov, I. I. (2008b). Sporangia formation in higher plants. Botanicheskii Zhurnal [Шамров, И. И. Формирование спорангиев высших растений. Ботанический журнал], 93 (12), 1817-1845 (in Russian).

Shamrov, I. I. (2015). Embryology and Plant Reproduction. St. Petersburg [Шамров, И. И. Эмбриология и воспроизведение растений. Санкт-Петербург]. 200 pp. (in Russian).

Shamrov, I. I., Anisimova, G. M., Babro, A. A. (2020). Early stages of anther development in flowering plants. Botanica Pacifica, 9 (2), 1-10.

Shamrov, I. I., Babro, A. A. (2008). Anther development and structure in Rhododendron schlippenbachii and R. luteum (Ericaceae). Botanicheskii Zhurnal [Шамров, И. И., Бабро, А. А. Развитие и строение пыльника у Rhododendron schlippenbachii и R. luteum (Ericaceae). Ботанический журнал], 93 (8), 61-80 (in Russian).

Solntseva, M. P. (1987). Family Asteraceae. In: Comparative Embryology of Flowering Plants. Davidiaceae-Tremandraceae. Nauka, Leningrad [Солнцева, М. П. Семейство Asteraceae. В кн.: Сравнительная эмбриология иветковых растений. Davidiaceae-Tremandraceae. Наука, Ленинград], pp. 318-331 (in Russian).
Sreenivasulu, N., Wobus, U. (2013). Seed-development programs: A systems biology-based comparison between dicots and monocots. Annu. Rev. Plant Biol., 64, 189-217.

Steer, M. W. (1977). Differentiation of the tapetum in Avena. I. The cell surface. J. Cell Sci., 25, 125-138.

Steffen, K., Landmann, W. (1958). Entwicklungsgeschichte und Zytologische Untersuchungen am Balkentapetum von Gentiana cruciata und Impatiens grandulifera. Planta, 50 (4), 423-460.

Taylor, M. L., Altrichter, K. M., Aeilts, L. B. (2018). Pollen ontogeny in Ruppia (Alismatidae). Int. J. Plant Sci., 179 (3), 217-230.

Teryokhin, E. S., Batygina, T. B., Shamrov, I. I. (1993). The classification of microsporangium wall types in angiosperms. Terminology and conceptions. Botanicheskii Zhurnal [Терёхин, Э. С., Батыгина, Т. Б., Шамров, И. И. Классификация типов стенки микроспорангия у покрытосеменных. Терминология и концепции. Ботанический журнал], 78 (6),16-24) (in Russian).

Teryokhin, E. S., Batygina, T. B., Shamrov, I. I. (2002). New approach to classifying modes ofmicrosporangium wall formation. In: Embryology of Flowering Plants. Terminology and Concepts. Vol. 1. Enfield (NH), USA, Plymouth, UK, pp. 32-39.

Tiagi, B., Taimni, S. (1963). Floral morphology and embryology of Vernonia cinerascens, Schult. and V. cinerea Less. Agra Univ. J. Res., 12, 123-137.

Tischler, G. (1915). Die Periplasmodenbildung in den Antheren der Commelinaceen und Ausblicke aus das Verhalten der Tapetenzellen bei den übrigen Monokotylen. Jarb. Wiss. Bot., 55 (1), 52-90.

Tiwari, S. C., Gunning, B. E. S. (1986). Development of tapetum and microspores in Canna L.: An example of an invasive but non-syncytial tapetum. Ann. Bot., 57 (4), 557-563.

Toderich, K. N. (1988). Embryology of sunflower (Helianthus annuus, H. rigidus and others). $\mathrm{Ph}$. D thesis. Komarov Botanical Institute, Leningrad. [Тодерич, К. Н. Эмбриология подсолнечника (Helianthus annuus, H. rigidus и другие). Дисс. канд. биол. наук. 256 с.] 256 pp. (in Russian).

Venkareswarlu, J., Lakshminarayana, L. (1957). A contribution to the embryolohy of Hydrocera triflora W. and A. Phytomorphology, 7 (2), 194-203.

Walter, R., Kuta. E. (1971). Cytological and embryological studies in Sonchus L. I. Sonchus asper (L.) Hill. and Sonchus oleraceus L. Acta Biol. Crac. Ser. Bot., 14, 103-109.

Received 14 July 2020

Accepted in the final form 24 November 2020

\section{SEGSĒKḶU PUTEKŠNĪCU TAPEŠSLĀṆU TIPI UN FORMAS}

Raksts ir pārskats, kurā atspoguḷoti pētījumi par segsēkḷu putekšnīcu tapešslāṇu veidiem. Lai gan ziedaugu putekšnīcas ir daudz pētītas, tomēr joprojām ir neatrisināts plašs problēmu loks, ieskaitot pretrunīgi lietoto terminoloğiju dažādās publikācijās. Raksta autori, balstoties gan uz citu pētnieku, gan uz saviem pētījumiem, piedāvā jaunu segsēkḷu putekšnīcu tapešslāṇu klasifikāciju. 